\title{
Tunnustus elinikäisen oppimisen moninaisissa käytännöissä
}

Andreas Fejes \& Magnus Dahlstedt (2013).

The Confessing Society. Foucault, confession and practices of lifelong learning.

London: Routledge. 122 s. ISBN: 978-0415-66037-2

ANDREas FEJEsin ja Magnus Dahlstedtin teos tarkastelee kriittisesti länsimaisille yhteiskunnille ominaista pyrkimystä tunnustuksellisuuteen ja omien sisäisten tuntojen sanoittamiseen ja paljastamiseen sekä itselle että muille. Tämä voi tapahtua puheen, kirjoituksen ja itsetarkkailun kautta niin yksityiselämässä kuin julkisestikin esimerkiksi tosi-tv-ohjelmissa ja sosiaalisessa mediassa. Kirjoittajat osoittavat genealogiseen analyysiin pohjautuen, kuinka tunnustuksesta on muodostunut teknologia, joka muokkaa kansalaisia, ja jota niin kutsuttu uusi media vahvistaa. Totuuden kertominen muotoutuu tunnustamisen tekniikoiden kautta elinikäisen oppimisen käytännöissä koulutuksessa, työssä ja yksityiselämässä. Kirjoittajat haluavat kyseenalaistaa ja tehdä näkyväksi elinikäisen oppimisen käytäntöihin liittyviä itsestäänselvyyksiä ja täten avata tiloja toisin tekemiselle.

\section{TERAPISOITUNUT YHTEISKUNTA}

Teoksen teoreettisena lähtökohtana on Michel Foucault'n myöhempi tuotanto tunnustuksesta (confession), minäteknologioista (technologies of the self) ja hallinnasta (governmentality). Ihmisiä rohkaistaan avautumaan unistaan, unelmistaan, uskomuksistaan ja peloistaan eri tavoin sosiaalisen elämän eri alueilla. Sanoittamalla sisäisiä tuntojaan he oppivat tuntemaan itsensä. Foucault'n mukaan "sanoittamisesta" on tullut keskeinen menetelmä, jonka kautta ihmiset tulevat näkyviksi itselleen ja toisille: asiantuntijalle kuten lääkärille, psykologille tai sosiaalityöntekijälle, ystävälle, perheenjäsenelle tai "virtuaaliselle toiselle". Huolimatta siitä, kuka kulloinkin on "asiantuntijan" asemassa, avautuminen itsessään rakentaa hierarkkisia suhteita siitä, mitä ajatuksia pidetään hyvinä, mitä huonoina ja millaiseksi subjekti kulloinkin muotoutuu. Kirjoittajat ovatkin kiinnostuneita siitä, miten tunnustus toimii, mitä pidetään hyväksyttävänä sekä millaista subjektia elinikäisen oppimisen moninaisissa käytännöissä rakennetaan. Myös Frank Furedi sekä Kathryn Ecclestone ja Dennis Hayes, joiden viimeaikaisiin teksteihin kirjoittajat viittaavat, ovat tarkastelleet yhteiskunnan terapisoitumista ja psykologisoitumista. He ovat tuoneet esiin, kuinka tunteilla ja terapeuttisilla käytännöillä on merkittävä rooli modernissa yhteiskunnissa.

\section{TUNNUSTUS OSANA OPPIMISTA}

Teos osoittaa, että tunnustuksen käsite tutkimuksen analyyttisenä työkaluna on edelleen ajankohtainen. Eri elämänalueille ulottuvat empiiriset esimerkit ja dokumentti-, haastattelu- ja media-aineisto- 
jen analyysit ilmentävät, kuinka tunnustus muokkaa ja hallitsee subjekteja erilaisissa elinikäisen oppimisen käytännöissä. Samalla tunnustus tulee osaksi sosiaalisen elämän eri osa-alueita ja rajat koulutuksen, työn ja yksityiselämän välillä sekoittuvat ja hämärtyvät.

Tutkimusesimerkit liittyvät formaaliin koulutukseen (esim. koulutukseen ja ammatinvalintaan liittyvä ohjaus, luku neljä; vuorovaikutus ja terapeuttiset tekniikat tulevaisuuden muutoksista ja haasteista selviämisessä, luku kolme), työssä oppimiseen (esim. reflektiiviset käytännöt kuten opetuskeskustelu ja oppimispäiväkirja vanhustyössä, luku kaksi) ja arkielämään (esim. vanhemmuuteen ja perhe-elämään liittyvät tosi-tv-ohjelmat, luku viisi). Kirjoittajat tuovat esiin, miten valta operoi elinikäisen oppimisen käytännöissä ja miten tunnustus on tärkeä teknologia, jonka kautta subjekteja muokataan ja hallitaan. Sisäänpäin katsomisesta, itsensä tuntemisesta ja omien vahvuuksien tunnistamisesta on tullut tärkeä osa elinikäistä oppimisen politiikkaa. Vain tuntemalla itsensä ja omat vahvuutensa voi tehdä oikeita valintoja elämässään. Tähän tarvitaan myös elinikäistä ohjausta.

Viidennessä medialisoitunutta vanhemmuutta käsittelevässä luvussa kirjoittajat kytkevät analyysin osaksi elinikäisen oppimisen käytäntöjä, jotka ulottuvat perhe-elämään ja mediaan. Luvussa esitetään, kuinka "oikeanlaista" ja "normaalia" vanhemmuutta rakennetaan tosi-tv-ohjelmissa tunnustamalla ongelmat ja ratkomalla ne julkisesti, jolloin myös katsoja voi samaistua niihin ja oppia niistä. TV ja sosiaalinen media, esimerkiksi Facebook, ovat keskeisiä välineitä omien kokemusten, ajatusten ja tunteiden jakamisessa julkisesti ja oman itsen näkyväksi tekemisessä.

\section{VASTARINNAN MAHDOLLISUUS}

Tekijät pyrkivät avaamaan toisin toimimisen mahdollisuuksia teoksen viimeisessä luvussa. Foucault'n innoittaman genealogisen analyysin tavoitteena on tehdä näkyväksi itsestään selviksi miellettyjä ajattelutapoja, jotta tila toisin tekemiselle tulisi mahdolliseksi. Emme voi kuitenkaan astua valtasuhteiden ulkopuolelle, koska valta on kaikkialla ja se on tuottavaa; me olemme vääjäämättä vallan muokkaamia.

Valtadiskursseja on kuitenkin mahdollista vastustaa. On mahdollista nojata marginaalissa oleviin diskursseihin, vaikka puhuva subjekti voidaan tällöin tuomita totuuden ulkopuolelle ja "väärässä” olevaksi. Marginaalidiskursseihin nojaaminen voi puolestaan avata tiloja uusille näkemyksille ja puhetavoille, jotka voivat muotoutua uusiksi totuuksiksi ja tehdä mahdolliseksi nykyisyyden elämisen toisin. Kirjoittajat tuovat esiin esimerkkejä keinoista vastustaa tunnustusyhteiskunnan käytäntöjä: kieltäytyä tunnustamasta, nojata marginaalissa olevaan diskurssiin tai ohittaa tunnustuksellisuus huumorin tai satiirin keinoin. Niin valtadiskursseihin tukeutumisella kuin vastarintaan asettumisellakin on kuitenkin omat seuraamuksensa, joita joutuu puntaroimaan va- lintoja tehdessään: puhuminen, hiljaisuus, osallistuminen, osallistumattomuus, valitseminen vai valitsematta jättäminen?

\section{MONIULOTTEINEN KUDELMA}

Teos pohjautuu kirjoittajien tekemään empiiriseen tutkimukseen ja aiemmin julkaistuihin teksteihin kasvatustieteen ja politiikan tutkimuksen aloilta. Kirjoittajat pyrkivät luomaan moniulotteisen ja kokonaisvaltaisen kuvan tunnustuksen soluttautumisesta sosiaalisen elämän eri alueille. Haasteena on useista tutkimusesimerkeistä koostuvan ja sosiaalisen elämän eri alueille ulottuvan analyysin rakentaminen yhtenäiseksi kokonaisuudeksi. Toisaalta eri elämän alueille liittyvät tutkimusesimerkit tuovat kiinnostavalla tavalla esiin tunnustuksen teknologian moninaiset ulottuvuudet.

Teoreettisten lähtökohtien ja käytettyjen käsitteiden ja niiden määrittelyiden avulla kirjoittajat sitovat eri sosiaalisen elämän aloihin liittyvät tutkimusesimerkit yhtenäiseksi kudelmaksi, joka valottaa tunnustuksen teknologian näkyvyyttä aikamme käytännöissä. Teos on kiinnostavaa ja ajankohtaista luettavaa kaikille yhteiskunnallisista kysymyksistä kiinnostuneille tutkijoille, opiskelijoille ja käytännön toimijoille.

\author{
Päivi Siivonen \\ Yliopistotutkija \\ Kasvatustieteiden ja psykologian \\ osasto \\ Itä-Suomen yliopisto
}

